IJSSP

$37,7 / 8$

374

Received 20 June 2016 Accepted 24 June 2016

\section{How close are formal and informal work?}

\author{
Joanna Shapland \\ School of Law, University of Sheffield, Sheffield, UK, and \\ Jason Heyes \\ Management School, University of Sheffield, Sheffield, UK
}

\begin{abstract}
Purpose - Recent changes in the UK to the regulation and modes of work in the formal and informal economies are considered. Research in this field has tended to remain in silos (treating formal economy working conditions separately from research on the informal economy). The question is whether the means of work and benefits to the worker for formal and informal work are now as different as the former images of formal and informal economy work imply under a "jobs-for-life" economy. The purpose of this paper is to consider whether the current aim of government regulation of the informal economy - to formalise it - is actually of benefit to workers, as might be supposed.

Design/methodology/approach - This paper considers recent research findings on the formal and informal economy, using official government statistics for the UK and more detailed European studies on the informal economy.

Findings - This paper argues that formal employment in the UK is becoming more casualised, with less associated benefits to employees. Though it is still of benefit to the state to formalise informal work (to increase tax take), some of the links between formalisation and a good working environment for workers are being broken, which may lead to the informal economy becoming more popular and requiring different priorities in its regulation.
\end{abstract}

Originality/value - This paper argues that we need to change our assumptions and image of work in the formal economy, compared to that in the informal economy.

Keywords Informal economy, Employment conditions, Criminal economy, Formal economy

Paper type Conceptual paper

\section{Introduction}

The most accepted definition of the informal economy sees it as the shadow, or other, of the formal economy. Hence, the informal economy has been defined as a productive activity that does not fall within the ambit of a country's GDP (International Labour Organisation, 2002). There have been differences amongst scholars as to whether it should be measured in terms of individual workers, or work or firms. However, the key distinction is between paid work which is declared (normally by firms/employers but sometimes by employees) to the state and on which state dues, such as taxes and insurance or pension contributions, are paid, and paid work which is not declared and on which no such dues are paid (European Commission, 1998).

In general, work has also been seen as falling into one of these two categories: formal or informal. It has often been assumed that a productive activity which is illegal, in the sense of being outside the criminal law, will then naturally fall within the informal sector. So, for example, it has been assumed that the importation, distribution and sale of illegal drugs and the illegal activities associated with prostitution (such as pimping, running a brothel or, in some countries, prostitution itself) will be in the informal economy. Doubt has been thrown

\footnotetext{
(C) Joanna Shapland and Jason Heyes. Published by Emerald Publishing Limited. This article is published under the Creative Commons Attribution (CC BY 4.0) licence. Anyone may reproduce, distribute, translate and create derivative works of this article (for both commercial \& non-commercial purposes), subject to full attribution to the original publication and authors. The full terms of this licence may be seen at http://creativecommons.org/licences/by/4.0/legalcode
}

International Journal of Sociology and Social Policy pp. 374-386 Emerald Publishing Limited 0144-333X DOI 10.1108/IJSSP-06-2016-0071 
on this assumption by the recent instruction from the EU to its member countries, acted upon by the UK in 2014, that some of these criminal activities should be included within GDP so that the measurement of GDP includes a better representation of work activity. In the UK, this has been done by the Home Office estimating the size of the illegal drug and prostitution markets (Monaghan, 2014). It is less clear whether the corollary is that drug importers and dealers and pimps are now expected to declare their income and pay the relevant dues (or whether, if they do so, they may then escape prosecution, though presumably, they will not be pursued by the Revenue and Customs for VAT, etc.).

There have been similar assumptions that, in return for declaration, workers in the formal economy receive benefits from the state and also some from their employers. In contrast, workers in the informal economy are not seen as benefiting from the regulation imposed by the state, so they will not automatically receive sick pay, holiday pay, good employment conditions inspected by workplace regulators, pensions, etc. Continuing in informal work over a period of time can leave workers (and their families) in poverty and without long-term rights (Katungi et al., 2006; Godefroy, 2003). Moreover, their employment is not normally subject to a written formal contract, so they can be fired without recourse to tribunals, subjected to physical enforcement methods if they are not performing (e.g. beaten up), not paid on time, etc. The contractual and regulatory framework for formal work is obviously different amongst different countries, so these benefits may be more or less applicable.

These assumptions that workers in the formal economy receive greater benefits than those in the informal economy depend to some extent though, on equating "state" and "employer". Hence, it tends to be assumed that if the state mandates or encourages particular aspects of employment law or employment relations, then employers will follow suit. Contractually, though, there is no such thing as a three-party contract, such that whatever one party requires, the other two obey. The state may wish for employer-employee relations to be of a certain order, but unless the state takes the powers to regulate that order and puts in mechanisms and funds to enforce the regulation of the order, it will not necessarily happen. As many have commented, regulation is only as good as its enforcement (Hawkins, 1984; Dickens, 2012). This implies a need for government agencies (i.e. labour inspectorates) that have the capacity to detect infringements of employment rights and take appropriate action against firms that are found to be non-compliant. Effective regulation also requires that workers (and other citizens) who suspect compliance failures are provided with means of alerting relevant authorities, and enforcement is much easier to attain for certain types of work and in certain types of environment. So, for example, there are clear standards for the guarding of machinery and holes in the ground, the pollution of rivers and the release of radioactive substances (see, e.g. Health and Safety Executive, 2015; Hawkins, 1984). It is much harder to measure and enforce the levels of stress in call centres or the risk of violence posed by the public in hospitals or shops (Health and Safety Executive, 2007). Furthermore, certain occupations, such as domestic workers and street vendors, and workplaces, such as family homes and micro-businesses, are particularly difficult to regulate effectively.

In this paper, we wish to raise the possibility that the assumptions that workers in the formal sector are better regulated and receive more protection in employment are increasingly being placed into doubt in England and Wales and some other Western countries by the changes in employment and the ways in which work is done. The distinctions between formal and informal work have arisen economically and sociologically in the last half of the last century (Verhage and Shapland, 2013), a time at which centralised forms of work organisation with predominantly formal employment (the so-called Fordist model of employment and work) were well established. The question is then whether such distinctions can still be applied with confidence to the world of work now? If, as a result, the benefits of formal employment for workers are less certain, does this 
IJSSP

$37,7 / 8$

cast more doubt on the stability of the implicit triangle of influence and power between the state, employer and worker? Are formal and informal employment becoming much more similar to workers? And so, are they becoming more similar for employers, to the detriment of the state? Or is this purely a result of the current growing dominance of the neo-liberal project (backed up by the global influence of the IMF, WTO, etc.) and a consequent decline of the social welfare model (requiring national state funding), and so potentially reversible to restore benefits to workers and potentially stability to the triangular compact?

\section{Patterns of work in the informal economy in the West}

It is very difficult to make definitive statements about "the informal economy", which apply to every activity under that heading, because there is such a variety of work and workers, as well as employers and consumers, involved in the different sectors. The informal economy spans across the transfer and sale of goods and a very wide variety of services, from the financial sector through construction, personal services and agriculture (such as fruit picking). For every statement about one kind of informal work, there is probably an example from elsewhere which countermands it. The continuing controversy whether the informal economy is primarily a survival economy or a playground for the rich bears this out (Saitta et al., 2013). Yet, there are some relatively general conclusions which we believe may be able to be drawn out about the nature of work in the informal economy because they stem from the informal (and sometimes illegal) nature of such activity.

Legal work in the informal economy (undeclared work) is typically concentrated upon service sectors, household work, entertainment and catering, retail, construction and seasonal work in agriculture, etc. It is common for much undeclared work to be a "bit on the side" - the undeclared work being additional to the formal work of a similar kind (such as in plumbing or construction) (Pacolet and De Wispelaere, 2013; Boels, 2013). Typically, workers work for themselves or are employed in small units, underpinned by the personal contacts and lack of contractual paperwork/invoices characteristic of the undeclared work.

Illegal informal economy work tends to be in the supply of personal services and goods to individuals (prostitution, drugs, etc.), though distribution networks for both may well involve a number of levels and organisations (drug importation, human trafficking, etc.). Again, however, contacts tend to be known and need to be trusted, which limits the size of the organisation. Some forms of illegal supply and work involve very significant amounts of money (e.g. art and heritage fraud (Massy, 2008) and also the illicit trade in animal parts (Van Asch, 2013) at the level near the final sale, as well as the supply of drugs (at the level of transnational importation)). The informal economy can definitely be about "getting rich" rather than "getting by" (Verhage and Shapland, 2013). However, most workers in the illegal informal economy (e.g. street-level drug dealers) earn very little money - and there is no minimum wage in the informal economy. This can encourage informal economic activities to be pursued as an additional income to more formal sources, and indeed illegal informal economic activity often mimics the trade routes and business methods of operation of more legal forms (Tarrius, 2003). It might be characterised as being parasitic on the formal economy (Nelen, 2008). So, heroin and cocaine travel in lorries carrying legal goods (Tarrius, 2003), or inside the furniture which is legally bought, etc. Stolen goods are sold in second-hand shops and on internet markets which exist primarily for legal sales.

Both legal and illegal work, though, need to be run through person to person contacts whether face-to-face, telephone or electronically - because of the need to avoid records and surveillance by the authorities. Moreover, personal trust is required. Though trust is key in most businesses, it is very difficult to "check out" new business, suppliers or customers when one's business needs to be kept under the radar. Due diligence requires a very different set of tools, largely dependent upon personal contacts and recommendations. We would argue that this has two consequences. First, businesses tend to be small 
(a set of trusted associates) or the work done on one's own account. Second, activities may be geographically limited because travel itself is risky and may attract notice. It is interesting in this regard that burglary in England is typically very local (one's burglar tends to come from the same town, indeed from the next few streets: Wiles and Costello, 2000), whereas there are much more long-distance burglars in mainland Europe (Van Daele et al., 2012). The difference lies in the proliferation of automatic number plate recognition cameras on English motorways and the barrier of the Channel, compared to the perceived lesser probability of recognition over long distances in mainland Europe.

The suggestion is, therefore, that overall informal work will tend to operate through small firms, geographically limited, or through self-employment. Expansion in size is difficult if there is effective regulation and scrutiny because work in the informal economy cannot rely upon documents or legal contracts and so depends upon face-to-face, largely personal, contacts. Though this is the case for illegal (criminal) work, we would venture to suggest that it also applies to undeclared work.

\section{Changing patterns of work in the formal economy in the West}

This pattern of working, which we have argued is the characteristic of informal work, is different from our image of the typical structure for formal work in Western countries. Here the constraints of illegality have not countered the pressures of capitalism, so companies seek to grow and indeed to monopolise. Though the majority of companies which are registered are small companies, if they are commercial entities (as opposed to partnerships), then typically we see such small companies as fledgling in one way or another. They may be new, small entrepreneurial outfits, or they may be struggling or the owners may have simply decided not to strive and to remain small - though this may not be a successful strategy.

The image that some (perhaps most) people have of the successful Western company is of a medium or large company, preferably a PLC (in UK terms: a public limited company). Though the company may have several workplaces, factories or shops of varying sizes, it will have many employees. Efficiency demands productivity and routinisation, so some large workplaces will be common. The image is essentially Fordist, based on the assembly line, whether that line be manufacturing, assembly or call centre. The growing use of electronic control has tended to shrink workforces, but these are still volume enterprises (at least in terms of product).

Elements of the Fordist model remain important in the UK, particularly in the services sector where companies such as Amazon rely on relatively routinized, intensively timemanaged operations and where many call centre operatives experience "an assembly line in the head" (Taylor and Bain, 2003). The Fordist model of employment relations (as opposed to work organisation), however, involving relative job stability, joint regulation of wages and conditions, and wages that rise in line with productivity, no longer reflects the experience of most workers. A number of developments since the 1980s have resulted in greater employment fragmentation and insecurity. Some of these tendencies were exacerbated by the economic crisis that began in 2008 .

If we consider the data provided by the Labour Force Survey, just looking at the headline rates of employment indicates that there appears to be relatively little effect of the recession. There was a slight dip in the employment rate from 2008 to 2010, followed by an increase that has continued to 2015 (Figure 1; European Commission, 2015). However, the distinction between "in employment" and "unemployed" hides the changes within working practices towards, essentially, "less employment".

First, the search for cost savings has led many organisations to rely on independent contractors for service support in areas such as finance, HR, IT, cleaning, reception, security, servicing, even mowing the grass. Those personnel may sometimes be based within the company's premises, but their line managers will be others. Although the proportion of
Formal and informal work 
IJSSP

$37,7 / 8$

\section{8}

Figure 1.

Activity, employment and unemployment rates, workers aged 15-64 years

(2004-2014)

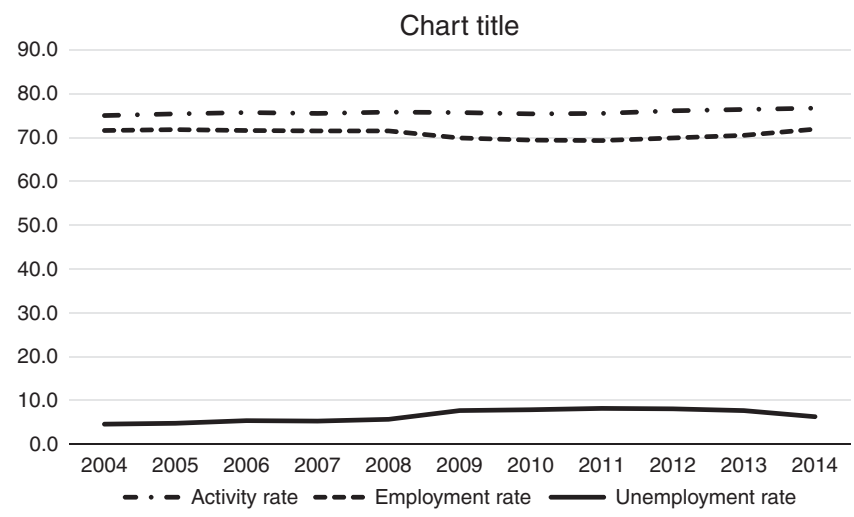

Source: Eurostat (lfsa_argan, lfsa_ergan and lfsa_urgan - European Commission, 2015)

workplaces that subcontract some activities appears not to have increased over the past ten years, contracting out of certain functions, notably security, has increased (Van Wanrooy et al., 2011, pp. 42-43). Outsourcing has become particularly prevalent in the public sector, where bodies such as the courts, police, prisons and health use agency or privately employed staff. This development can be traced back to the 1980s and the introduction of compulsory tendering requirements in England and Wales. Privatisation since the 1980s has also encouraged a proliferation of different contracting arrangements. If we think of a railway station, for example, the train crew, signallers, platform staff, café staff, shop staff, ticket sales, car park staff and engineers are all likely to be employed by different companies.

Second, it is well known that the growth of service sector employment since the 1980s has been associated with an increase in part-time employment and variable hours contracts. Much of the growth took place in the 1980s and early 1990s, and since the late 1990s, the proportion of UK employees in part-time jobs has been relatively stable (around one-quarter). There was a slight increase after the start of the crisis, from 24.2 per cent in 2008 to a peak of 26 per cent in 2012[1], since when there has been a slight fall. More significant, however, has been the increase in underemployment since 2008 . The proportion of those working parttime because they could not find a full-time job (i.e. those in involuntary part-time employment) increased from 10.6 per cent in 2007 to 20.3 per cent in 2013 , which is by far the largest proportion since the early 1980s.

Further evidence of the growth in underemployment is provided by the Bell-Blanchflower Underemployment Index, which measures the excess supply of hours in the economy, adding the hours that the unemployed would work if they could find a job with the change in hours that those in work would prefer, expressed as a percentage of the sum of hours worked and surplus hours. If one considers Bell and Blanchflower's (2015) plot of both underemployment and unemployment, the graphs, seasonally adjusted, run almost exactly in parallel between 2001 and 2007, but then start to diverge in 2008 (although still showing similar peaks and troughs). Underemployment, since the start of the current economic recession, has become a much more major element in excess hours available in the economy.

It has been argued that there may also be an increase in portfolio employment (Sennett, 2011), in which one worker may have several jobs at one time. Unfortunately, although the Labour Force Survey counts the number of workers with a second job, it does not count the number of paid jobs per worker, so we cannot be certain. It is possible, however, that recent shifts towards more casualisation and underemployment may have led to an increase in 
multi-employment, which has echoes of the nineteenth century and before, when every cottage in a village tended not just to be, for example, a small farmer, but also a brewer and alehouse keeper, seamstress, etc.

Third, the perceived experience of many within the labour force has definitely been a harsher one and a more precarious one over the last few years. There has been a decrease in public sector employment, compared to private sector employment (with jobs in the public sector tending to be less risky in terms of hours than those in the private sector). The decline in trade union presence within workplaces, coupled with a permissive legal framework, has also enabled employers to engage in practices aimed at maximising the numerical and temporal flexibility of their workforces, resulting in work that is highly insecure. The apogee of part-time, more risky formal employment is exclusive zero-hour contracts, in which the company does not guarantee any paid working hours to the employee, and which also prohibit the worker from obtaining jobs elsewhere. Although recent changes to the law mean that exclusivity clauses in zero-hour contracts have been unenforceable since May 2015[2], the basic form of employment remains entirely legal and indeed formal employment (the employer pays the state all necessary moneys for the hours actually worked by the employee). The Office for National Statistics (2015a) has estimated that 697,000 people were employed on zero-hour contracts as their main job between October and December 2014 (2.3 per cent of the UK workforce). However, potentially, such a contract means that the employee is withdrawn from formal employment if the company does not choose to employ them in any particular week and if they are unable to obtain work from an alternative employer. If the worker does obey such a contract and the company does not provide the hours, in fact, the public sector and/or the charitable, voluntary sector are subsidising the company, through benefits payable in the case of very low wages and through food banks, etc. Very similar effects pertain if companies do not obey the minimum wage limit, rendered more likely if there is poor enforcement of such limits (or contracts).

Fourth, are the workers we can see in company premises actually employees at all, or are they self-employed? Self-employed people of course bear the brunt of paying welfare elements of state taxation themselves, and have to provide their own pensions, sick leave, holiday pay, etc. Since mid-2010, there has been a growth in jobs, but a significant number of these jobs have been self-employed jobs - self-employed persons account for one-third of the additional employment created between spring 2010 and autumn 2014. However, it is clear that though self-employment is a positive choice for some (as indeed are zero-hour contracts for a few), many would prefer actually to be employed on a normal contract of employment, and much of the new self-employment is low paid and precarious (Heyes, 2015; D'Arcy and Gardiner, 2014). Overall, the number of those self-employed in the UK has grown by 650,000 since 2008, to reach nearly 15 per cent of all employment in 2015 (Office for National Statistics, 2015b). Most of these self-employed workers have no pension.

Fifth, young workers have been particularly hard-hit by the economic crisis and continue to experience substantial difficulties in making the transition from education to work. The unemployment rate for workers aged 15-64 years increased from 5.3 per cent in 2007 to 8.2 per cent in 2011, before falling to reach 6.3 per cent in 2014. By contrast, workers aged 15-24 years experienced an increase from 14.3 per cent in 2007 to 21.3 per cent in 2008, falling to 16.9 per cent in 2014[3]. Although the position of young people has clearly improved compared to the height of the economic crisis, their connection to the labour market is more uncertain than that of older workers, and gaining a foothold remains extremely difficult for many. Apprenticeships offer one route and the government has committed to increasing the number of apprenticeship places available in the economy. Some of these places are being snapped up not just by school leavers but those in their $20 \mathrm{~s}$. In some sectors in the UK, unpaid internships are the only way in (media, international bodies, PR, etc.), and patronage is rife. Some occupations require a period of
Formal and informal work 
IJSSP

$37,7 / 8$

self-employment before a semi-permanent contract may be acquired (e.g. in professional orchestras). Entering work is becoming a less well-paid, more precarious matter - and entering some work is really only possible with family support.

Sixth, exiting work has also seen major changes. Retirement on a full pension which provides enough to relax upon is becoming rarer and is likely to phase out for the majority of workers in the next 20-30 years in the UK. In order to live (given that parsimonious states are unlikely to be profligate with state pensions), workers are likely to be faced with working longer into their $60 \mathrm{~s}, 70 \mathrm{~s}$ and $80 \mathrm{~s}$. The jobs available then, though, may not be the same jobs as in the prime of life. Supplementing pensions, workers are likely to take on part-time work, possibly less exacting work. Having a portfolio of income is likely to occur for the elderly as well.

Seventh, if one looks inside a building, one may also find few, if any, employees there. Since offices are expensive, equipping employees to work from home may be cheaper - or just expecting them to work from home, coming in to work for periodic meetings. Evidence suggests that there has indeed been an increase in the extent of employees working from home. An analysis of Labour Force Survey data undertaken by the Trades Union Congress (2013) found that a little over 4 million employees normally worked from home in 2012, an increase of 470,000 since 2007 . The ability to work at a distance afforded by IT is changing the landscape of companies towards hot-desking and home working. It is also making worker-manager relations more distant, which will tend to depersonalise contacts and reduce workers' inclinations to "step in" and help when other employees have difficulties, etc.

The combination of all these factors may have lessened the dominance of centralised forms of work organisation in the UK economy and weakened the ties that bind employees and employers. We may, in some sectors where there is not a need to gather employees together, be moving back fast to the era of piece work and home working. Communication between workers (and bosses) may not even be face-to-face, but electronic, at a distance, with periodic face-to-face encounters.

Another factor linked to the increasingly distant workplace, and which may also be promoting the informal economy, is the state's need to check on these elusive workers. States and employers are colluding to require employers to undertake more checks of workers before formal employment can commence. In the UK, these include checking nationality documents (for border control and immigration reasons), checking that the employee does not have a criminal record and checking educational and skills qualifications, as a normal part of due diligence by employers before hiring. The latter has ramped up employers' requirements for potential workers to be able to show pieces of paper proving their qualifications, rather than just possessing those abilities with them being tested over probationary periods. Probationary periods would of course have been paid periods. The need to be able to show documents is a disadvantage for those whose education or training has been difficult (including those who have been excluded from school) or who have not been able to afford the qualifications. This substantially disadvantages those who are trying to desist from crime or have criminal records (Farrall et al., 2010). It also, though, renders it difficult for those who come from poor backgrounds without much social capital to acquire the papers, or the internships, or pull themselves out of the not-in-work underclass. Though employers have (rightly) protested at the extra burdens state imposition of these checks have created, they do actually lower the risk of taking on unqualified staff for the distant workplace, where probationary periods have become more difficult to provide because they involve supervision by trained workers.

Though the concurrence of these changes may be a peculiarly British phenomenon, the pace of change in the formal workplace has been fast. Though employers may have been 
propelled to consider change because of the economic recession and its pressures, some seem eagerly to have embraced the changes in work towards flexible contacts and subcontracting. A logico-rational economic response would be, "Of course, it is in businesses' financial interests to have more flexible arrangements". However, what is most financially advantageous at one moment in time may not be most beneficial in the long term. The downside of flexibility is the potential for a greater turnover of workers and the loss of skills and institutional memory. If training costs are minimal and the supply of workers is good, then turnover may not be problematic (namely, in call centres and in hospitality, where turnover is expected). However, there are clearly greater potential risks in greater turnover to high-quality production or service delivery.

The other notable element to the fast pace of change in formal work patterns is that employers do not seem to have been held back from moving to lower wage rates or zerohour contracts by any perceived dissonance with employer-employee workplace culture. The International Labour Office has drawn together a cluster of attributes of what it calls "decent work", including adequate and safe working conditions, reasonable and reasonably stable incomes, definite working status and accessibility to labour protection legislation[4]. These can also be represented as elements of what one might term a "decent working culture", which would be seen as part of a compact between the employer, worker and state. Here again, we have seen an erosion, exacerbated by recently enacted government policies. Beginning with the "bonfire of the quangos" in 2010, the current Conservative government and the coalition government that immediately preceded it have weakened the content of employment protection legislation and the mechanisms through which it is enforced. For example, in April 2012, the minimum period one needed to have worked for an employer to be protected under the unfair dismissal rules was increased from one year to two years. The fees for a worker taking cases to Employment Tribunals (which deal with unfair dismissal cases) have substantially increased. As a consequence, the number of applications to Employment Tribunals has massively decreased (Ministry of Justice, 2015), raising concerns about the extent to which workers are being denied access to justice. In addition, the government has made it easier for employers to dismiss staff who are deemed to be "under-performing" by introducing measures to facilitate "consensual termination" of the employment relationship through ACAS conciliation, settlement agreements and "protected conversations" between employees and employers[5].

What is notable is that recent shifts in formal employment have occurred without any particular soul-searching among employers about departing from that decent working culture. There has, of course, been adverse comment, but this has been in the media and to a limited extent in Parliament, not amongst employers. The interesting element for employers in departing from such a decent working culture is that it is likely to have ramifications for their business. One such corollary is that they may develop in essence two workforces producing their product or working on their premises - a full-time workforce employed directly by that employer and within the decent working culture, and a more part-time or casualised workforce which may be employed directly or employed by agencies or a subcontractor, which does not benefit from the decent working culture. This bifurcation is not a recipe for continuing workforce harmony, though it can sometimes be used to drive down any demands by the permanent workforce to improve their conditions (by threatening them with demotion to the other workforce).

A second corollary is that workers who are not tied into the decent working culture may not feel any allegiance to that employer or need to deliver high standards, if they can get away with it. This is in essence continuing the process noted by Sennett (2011) about the move to portfolio careers with less loyalty to one employer in the long term. It is effectively compressing the attributes he noted into smaller time spans, or even simultaneously, where the worker is working for several employers or has several contracts.
Formal and informal work 
IJSSP

$37,7 / 8$

382

Third, a lack of loyalty felt by the workforce, because it is not a decent working culture, may in fact loosen any perceived barriers to engaging in the informal economy for workers' own benefit. So, doing a "bit on the side" - using the firm's contacts and equipment on work which employees do themselves without informing managers - may be promoted. Changing workplace cultures can promote those aspects of the informal economy which involve those in formal work. We have known for a long time that some management cultures (those which emphasise outcome over method, ultra-competitiveness between staff and high rewards) promote corruption, fraud and financial scandals[6]. We are arguing that other management cultures, and particularly those which move, without regret, away from a decent working culture, may promote other forms of the informal economy.

We have argued, therefore, that there has been, in certain respects, a decisive shift in formal employment in the UK away from centralised forms of work organisation with a stable formal employment relationship to older traditions of more part-time, sub-contracted, geographically separated work. We also suggest that this is being accompanied by changes in the work culture which demote long-term loyalty and face-to-face care between the employer and worker, and promote short-term ends for both, as well as a more remote preemployment checking of workers. We have seen some of the advantages and disadvantages of this for the employer.

If we consider, then, the advantages for the worker in formal employment, the much acclaimed advantages of the formal seem to be less viable and present. Long-term pension benefits are falling with the changes in pension provision, and greater mobility throughout careers. Out of work benefits are being squeezed by states. Short-term employer-provided benefits (sick pay, holiday pay) are not always available on flexible contracts. There are health and safety dangers in at a distance working and home working (from stress, being a lone worker and less safe offices) - but they typically have not been as researched or enforced as health and safety dangers in large, particularly manufacturing places of employment. It is also not clear whether employers can exert control over health and safety at home.

The third partner in the worker-employer-state compact exemplified by the decent working culture is the state. It is not clear that the state has been affected very much or certainly very adversely by these changes in formal working. Smaller businesses and more at a distance working may cause slightly more work for the state in administering taxation, but they also create less work for the state in undertaking enforcement. Many regulatory measures, though they apply to all sizes of business, are only enforced for medium and large companies and for higher risk occupations and buildings (one example is health and safety inspections). The key issue for the state is the tax take - and any form of formal employment produces very similar tax takes in relation to taxes based on workers[7]. The direct interest of the state may then be neutral - which may explain why there has been relatively little governmental interest in these changes in formal employment.

\section{Should there then be a move towards formalisation?}

The emphasis on controlling the informal economy, as far as legal work is concerned (undeclared income), has, in recent years, been on formalising the informal, rather than trying to remove it entirely (International Labour Organisation, 2014; Barbour and Lilanes, 2013). In contrast, the rhetoric of dealing with illegal work (drugs, prostitution, trafficking, stolen goods market, counterfeiting, etc.) has continued to be about war and control, at least at the political level. However, action at the operational level of policing and regulation has shifted to management and enforcement driven by risk (Seddon et al., 2008). Both control and management, though, seek to minimise the extent of occurrence of the informal work, rather than to transform it into legal work. 
Whilst illegal criminal work continues to be seen as criminal (e.g. as opposed to just detrimental to health), this is unlikely to change. Where there have been changes in how the work is viewed in a normative sense, enforcement has however changed. So, for example, the regulation of prostitution in towns in which the authorities do not seek to stop it entirely has moved to trying to ensure the safety of the workers (and surrounding citizens) (Boels, 2015).

In relation to undeclared work, it is becoming less clear to us whether the emphasis should be on all aspects of formalisation, if formalisation means becoming like formal work. Some aspects of formalisation would clearly be of benefit to workers, employers and the state (e.g. better ways of enforcing contracts than shouting and blows, and some regulation by state-linked agencies). However, since formal work seems, in other aspects, to be moving away from a "decent working culture", do we want to promote uncritically formalisation which produces this kind of work? For the state, any effective kind of formalisation produces benefits because formalisation increases the tax take. Formalisation hence promotes an effective redistribution of wealth, provided that taxes are used to reduce inequality, rather than promote it. That is a significant normative argument for promoting formalisation.

For workers, though, more impersonal, document checking but equally precarious formal work may actually not have many more benefits (if employer and employee are in harmonious relations) than the person-oriented, informal work found, for example, in more lower-class areas by Williams and Windebank (2001). For employers, without reducing the paper burden, there would seem to be both cost and time disadvantages to formalisation. It may be time to try to pry apart the various strands behind formalisation and see which are beneficial and to whom.

Some of the major disadvantages of informality, however, remain and distinguish the informal from the formal. As indicated above, one key disadvantage of informality is the risk of corruption, bribery, brutality and simple non-payment for the work done by employers where there can be no recourse to formal agencies or regulators. There are corresponding risks for employers if workers denounce them to regulators. These advantages of the formal stem largely from the fact that formal work is registered with the state. The question is then whether such registration is worth the costs and work involved. The answer to that lies in whether the state is prepared to intervene where abuse is reported - i.e. whether registration does actually lead to investigation and action if abuse is reported. The ability and wish of state regulatory agencies to intervene to stop malpractice are not clear in all areas because, currently, regulation of the informal is controlled by top-down policies and strategies of inspection, which tend to serve state ends. It may be that, in this new era of work, if formalisation is to succeed, its regulation may need to move away from top-down, state-promoted uniformity and inspection towards a more responsive mode of intervention if contacted in relation to abuse.

\section{Notes}

1. Figures are from EU Labour Force Survey data reported by Eurostat. Data are for workers aged 15-64 years [lfsa_eppga].

2. The relevant legislation is Section 153 of the Small Business, Enterprise and Employment Act 2015.

3. EU Labour Force Survey data, reported by Eurostat (European Commission, 2015: lfsa_urgan).

4. We are translating these from their list of "acute decent work deficits", which they see as characterising the informal economy: "most people engaged in the informal economy are exposed to inadequate and unsafe working conditions, and have high illiteracy levels, low skill 
IJSSP

$37,7 / 8$

384

levels and inadequate training opportunities; have less certain, less regular and lower incomes than those in the formal economy, suffer longer working hours, an absence of collective bargaining and representation rights and, often, an ambiguous or disguised employment status; and are physically and financially more vulnerable because work in the informal economy is either excluded from or effectively beyond the reach of social security schemes and safety and health, maternity and other labour protection legislation" (International Labour Organisation, 2014, p. 3).

5. Where an employer offers to end an employment relationship on agreed terms (i.e. for financial compensation), the details of the "conversation" cannot be used as evidence in an Employment Tribunal, should the employees subsequently wish to claim that they were unfairly dismissed.

6. See, for example, the Treadway Report (1987). Recent examples of such cultures, coupled with lack of regulation, are in the trading scandals affecting the setting of financial exchange rates in the financial sector.

7. Capital taxes and corporation taxes will be affected by the size of buildings and companies.

\section{References}

Barbour, A. and Lilanes, M. (2013), Supporting People to Legitimise Their Informal Businesses, Joseph Rowntree Foundation, London, available at: www.jrf.org.uk/sites/files/jrf/small-businessformalisation-full.pdf

Bell, D. and Blanchflower, D. (2015), The Bell-Blanchflower Underemployment Index Quarter 22011 Quarter 3 2014, The Work Foundation, Lancaster, available at: www.theworkfoundation.com/ Datalab/The-BellBlanchflower-Underemployment-Index (accessed 4 December 2015).

Boels, D. (2013), "The Belgian informal economy: a case study of seasonal work in fruit-growing in South Limburg", in Saitta, P., Verhage, A. and Shapland, J. (Eds), Getting by or Getting Rich? The Formal, Informal and Criminal Economy in A Globalised World, Eleven, The Hague, pp. 201-222.

Boels, D. (2015), "The challenges of Belgian prostitution markets as legal informal economies: an empirical look behind the scenes at the oldest profession in the world", European Journal on Criminal Policy and Research, Vol. 21, pp. 485-507.

D'Arcy, C. and Gardiner, L. (2014), Just the Job - Or a Working Compromise?, Resolution Foundation, London, available at: www.resolutionfoundation.org/wp-content/uploads/2014/05/Just-the-jobor-a-working-compromise.pdf (accessed 4 December 2015).

Dickens, L. (Ed.) (2012), Making Employment Rights Effective: Issue of Enforcement and Compliance, Oxford, Hart.

European Commission (1998), On Undeclared Work, COM (1998) 219, European Commission, Brussels.

European Commission (2015), Eurostat Datasets, European Commission, Brussels, available at: http:// ec.europa.eu/eurostat/data/database (accessed 17 December 2015).

Farrall, S., Bottoms, A.E. and Shapland, J. (2010), "Social structures and desistance from crime", European Journal of Criminology, Vol. 7 No. 6, pp. 546-570.

Godefroy, T. (2003), "L'économie informelle vue du Côté Français: une économie 'plurielle'?", in Shapland, J., Albrecht, H.-J., Ditton, J. and Godefroy, T. (Eds), The Informal Economy: Threat and Opportunity in the City, Max Planck Institut für ausländisches und internatinales Strafrecht, Freiburg-i-Br., pp. 249-322.

Hawkins, K. (1984), Environment and Enforcement: Regulation and the Social Definition of Pollution, Clarendon Press, Oxford.

Health and Safety Executive (2007), Managing the Causes of Work-Related Stress, Health and Safety Executive, London. 
Health and Safety Executive (2015), "Guidance”, HSE, London, available at: www.hse.gov.uk/guidance/ index.htm (accessed 12 June 2015).

Heyes, J. (2015), Job Creation Under the Coalition Government, Sheffield Political Economy Research Institute blog, Sheffield, available at: http://speri.dept.shef.ac.uk/2015/04/30/job-creationcoalition-government (accessed 4 December 2015).

International Labour Organisation (2002), Women and Men in the Informal Economy: A Statistical Picture, International Labour Office, Geneva.

International Labour Organisation (2014), "Transitioning from the informal to the formal economy", Report V(1), International Labour Conference 103rd Session, ILO, Geneva.

Katungi, D., Neale, E. and Barbour, A. (2006), Need Not Greed: Informal Paid Work, Joseph Rowntree Foundation and Policy Press, London.

Massy, L. (2008), "The antiquity art market: between legality and illegality", International Journal of Social Economics, Vol. 35 No. 10, pp. 729-738.

Ministry of Justice (2015), Tribunals and Gender Recognition Certificate Statistics Quarterly, October to December 2014, Ministry of Justice Statistics Bulletin, 12 March, available at: www.gov.uk/ government/uploads/system/uploads/attachment_data/file/411604/Tribunal-GRC-statisticsquarterly-oct-dec-2014.pdf (accessed 17 December 2015).

Monaghan, A. (2014), "Drugs and prostitution to be included in UK national accounts", The Guardian, 29 May, available at: www.theguardian.com/society/2014/may/29/drugs-prostitution-uknational-accounts (accessed 17 December 2015).

Nelen, H. (2008), "Real estate and serious forms of crime", International Journal of Social Economics, Vol. 35 No. 10, pp. 751-762.

Office for National Statistics (2015a), A01 Labour Market Statistics Summary Data Tables, Office for National Statistics, London, available at: www.ons.gov.uk/ons/rel/lms/labour-market-statistics/ june-2015/table-a01.xls (accessed 4 December 2015).

Office for National Statistics (2015b), EMPO1 (SA), Full-Time, Part-Time and Temporary Workers (seasonally adjusted), Office for National Statistics, London, available at: www.ons.gov.uk/ons/rel/lms/labour-market-statistics/december-2015/table-emp01-sa.xls (accessed 17 December 2015).

Pacolet, J. and De Wispelaere, F. (2013), "The informal economy and the present economic crisis in Europe: is there an influence", in Saitta, P., Verhage, A. and Shapland, J. (Eds), Getting by or Getting Rich? The Formal, Informal and Criminal Economy in a Globalised World, Eleven, The Hague, pp. 11-28.

Saitta, P., Verhage, A. and Shapland, J. (2013), Getting by or Getting Rich? The Formal, Informal and Criminal Economy in a Globalised World, Eleven, The Hague.

Seddon, T., Ralphs, R. and Williams, L. (2008), "Risk, security and the 'criminalization' of British drug policy", British Journal of Criminology, Vol. 48 No. 6, pp. 818-834.

Sennett, R. (2011), The Corrosion of Character: The Personal Consequences of Work in the New Capitalism, W.W. Norton, New York, NY.

Tarrius, A. (2003), "Drogues, communautés d'étrangers, chômage des jeunes et renouveau des civilités dan une ville moyenne française", in Shapland, J., Albrecht, H.-J., Ditton, J. and Godefroy, T. (Eds), The Informal Economy: Threat and Opportunity in the City, Max Planck Institut für ausländisches und internatinales Strafrecht, Freiburg-i-Br., pp. 37-46.

Taylor, P. and Bain, P. (2003), “'An assembly line in the head': work and employee relations in the call centre”, Industrial Relations Journal, Vol. 30 No. 2, pp. 101-117.

Trades Union Congress (2013), "Home-working on the increase despite the recession", available at: www.tuc.org.uk/workplace-issues/work-life-balance/04-homeworkers/home-working-increasedespite-recession-says-tuc (accessed 17 December 2015).

Treadway, J. (1987), National Commission on Fraudulent Financial Reporting - The Treadway Report, National Commission on Fraudulent Financial Reporting, New York, NY. 
Van Asch, E. (2013), "The illegal wildlife trade and transnational organized crime", in Saitta, P., Verhage, A. and Shapland, J. (Eds), Getting by Or Getting Rich? The Formal, Informal and Criminal Economy in a Globalised World, Eleven, The Hague, pp. 147-166.

Van Wanrooy, B., Bewley, H. and Bryson, A. (2011), Employment Relations in the Shadow of Recession: Findings from the 2011 Workplace Employment Relations Study, Palgrave, London.

Van Daele, S., Vander Beken, T. and Bruinsma, G. (2012), "Does the mobility of foreign burglars fit the general pattern of mobility?”, European Journal of Criminology, Vol. 9 No. 3, pp. 290-308.

Verhage, A. and Shapland, J. (2013), "Getting by or getting rich, or simply looking for a better life? The informal economy in times of economic crisis", in Saitta, P., Verhage, A. and Shapland, J. (Eds), Getting by or Getting Rich? The Formal, Informal and Criminal Economy in a Globalised World, Eleven, The Hague, pp. 389-404.

Wiles, P. and Costello, A. (2000), The 'Road to Nowhere': The Evidence for Travelling Criminals, Home Office, London.

Williams, C. and Windebank, J. (2001), "Reconceptualising paid informal exchange: some lessons from English cities", Environment and Planning A, Vol. 33 No. 1, pp. 121-140.

\section{Corresponding author}

Joanna Shapland can be contacted at: j.m.shapland@sheffield.ac.uk

For instructions on how to order reprints of this article, please visit our website: 